\title{
A Systematic review on soft skills development among university graduates
}

\author{
Joanna Bunga Noah ${ }^{1^{*}}$ \& Azlina Binti Abdul Aziz \\ ${ }^{1}$ Fakulti Pendidikan, Universiti Kebangsaan Malaysia, Bangi, Selangor, Malaysia \\ *email: joannabnoah@gmail.com
}

Received: 14 April 2020; Accepted: 27 May 2020; Published: 30 May 2020

To cite this article (APA): Noah, J. B., \& Abdul Aziz, A. (2020). A Systematic review on soft skills development among university graduates. EDUCATUM Journal of Social Sciences,6(1), 53-68. https://doi.org/10.37134/ejoss.vol6.1.6.2020

To link to this article: https://doi.org/10.37134/ejoss.vol6.1.6.2020

\begin{abstract}
In order to be employed, an individual needs to not only have the required knowledge but also a skill set that would allow the individual to perform the task well. Both the required knowledge and the skill set needed can be obtained from tertiary education at universities and higher institutions. However, it seems that graduates are lacking in that skill set, namely, soft skills. This paper is a systemic review on what soft skills employers value and yet are lacking among graduates and what are the roles of universities and the government pertaining to this issue. The findings have shown that the graduates are lacking soft skills that are highly valued by the employers. To overcome this issue, universities and the government has a part to play in order to build and develop the nation's human capital.
\end{abstract}

Keywords education, labour market demands, Human Capital Theory, soft skills, university graduates

\section{INTRODUCTION}

Soft skills should be fundamentally instilled in an individual from young, at home and since primary education (Cimatti, 2016). However, at tertiary levels, students are more aware of soft skills and its relation to their future careers. This awareness should also be their personal motivation to work on developing their soft skills with the aid of the university's curriculum. Soft skills are not connected to specific tasks or discipline but having soft skills is important to maintain relationships with other people the individual is working with. This is why soft skills is given focus when it comes to recruiting and throughout an individual's career at the organisation. This is because the soft skills that an individual possess can in a way contribute to greater outcomes and productions of a particular company (Tang, 2019; Cimatti, 2016).

University graduates are in hope that by obtaining a degree it will enable them to secure good positions in the workforce and thus have bright career ahead. On the other hand, employers look to hire prospects that are not only equipped with knowledge in a particular field, but also with certain abilities, namely soft skills that can enable them to get the job done (Tang, 2019). The importance of employees to have soft skills is with the assumption that these skills can enable one to complete various tasks (Gruzdev et al., 2018). Furthermore, Gruzdev et al. (2018) have concluded that employers are in agreement that in order for prospects to be hired, they should have significant soft skills which are currently inadequate in university graduates. This is why universities have the responsibility to assist with students' soft skills development required upon graduation for employability purposes. However, even with the implementation of various courses, the graduates do not seem to be well-equipped with soft skills that would aid their employment. Also, the number of graduates does not tally the number of those getting employed and this issue is raising concern among the parliamentarians and the public (Grapragasem et al., 2014). 
Despite the growing number of graduates to fit labour market demands for workers with higher academic knowledge, employers still have difficulties recruiting graduates as they tend to lack in the soft skills aspect. The complaints from the industry are giving added pressure to academic institutions (Okolie et al., 2019; Tang, 2019; Gruzdev et al., 2018).

Unemployment due to lack of related soft skills is a global issue to most graduates. Based on reports cited in Okolie et al. (2019), the UK and Nigeria are also facing problems where employers are finding it difficult to recruit graduates as there are skills mismatch between the university graduates and the demands of the employers. In the UK, employers recruit graduates based on three factors, which are work attitude (86\%), work aptitude (63\%) and academic competency $(43 \%)$. As can be seen here, employers place work related skills above and higher than academic ability which only further proves the importance of graduates acquiring soft skills for employability.

Employers are concerned about students' acquisition of skills that are relevant to labour market demands. Despite students acquiring discipline related skills, employers are still dissatisfied with graduates' soft skills (Okolie et al., 2019; Orji, 2013). It has been established that employers are much more focused on soft skills instead of hard skills when it comes to hiring their employees (Fahimirad et al., 2019; Tang, 2019). Soft skills such as leadership, teamwork, communication, entrepreneurship, thinking skills, interpersonal skills and management skills are all attributes that employers look for. This applies not only to entry-level workers or fresh graduates but also to experienced workers searching for a new job.

This rising issue that gradutes are lacking in soft skills thus not being employed can be due to the fact that graduates are more concerned about their future career and its development that they forget to be realistic at first. They tend to overrate themselves and believe that with certification they are competent enough to enter the labour market (Shakir, 2009). Graduates can only have a career and develop it well if they land a good job in the first place. In order to land the job, maintain and progress through it, they would need to start with building a resume, attend interviews, undergo training, and then slowly climb up the ladder (Tsaoussi, 2020). All these require soft skills development that would aid career progression. Therefore, graduates themselves need to be aware of what soft skills are important in the labour market, what soft skills they lack and take the opportunity to hone those skills while they are at the university (Shakir, 2009).

This research objective is to gather evidence from previous studies related to graduates' soft skills development. It aims to answer the following research questions: 1) What soft skills do employers value?; 2) What soft skills are lacking among university graduates?; 3) How can the university address the lack of soft skills among graduates?; and 4) How can the government address the lack of soft skills among graduates?

\section{LITERATURE REVIEW}

\section{Definition of Soft Skills}

Soft skills are skills that complement an individual's hard skills and they can enhance interactions, performance and career development. Soft skills include personality traits, sociability, language fluency and personal habits. Usually the accompaniment of soft skills to hard skills is the requirements of a profession especially if the profession deals greatly with other individuals (Pachauri \& Yadav, 2013). According to Fahimirad et al. (2019), skills and personal attributes affect an individual's employability. Some students are aware of it, thus they make efforts to improve their skills set while studying at the university. This also calls for more opportunities to be provided to these students to acquire soft skills throughout their academic years.

According to Tsaoussi (2020), soft skills can be widely applied across any job and they can be mastered as an ongoing journey. Graduates may attain soft skills at their universities but they would always encounter new situations, which would not only put their soft skills to use but also further sharpen it. Communication skills, creativity, thinking skills, management and leadership skills, problem solving, social responsibility, lifelong learning and teamwork are among the frequently emerging skills (Fahimirad et al., 2019). 
Soft skills can also be personal or interpersonal, development of both would aid an individual to be able to face many situations especially at work. Personal skills comprise of processing knowledge, ability to think and make critical judgments, desire for lifelong learning and planning and achieving goals. Interpersonal skills refer to relationships with other individuals, which includes communication skills, listening, negotiating, networking, problem solving and making decisions (Tsaoussi, 2020; Cimatti, 2016).

Basically the idea of soft skills in an individual is to aid and enhance work performance, which is why individuals that exhibit soft skills are much more favourable to employers.

\section{Human Capital Theory}

Nations are investing in education that can produce competent graduates who are independent and confident human capitals. Human capitals of each country and their development is important and necessary as they are the future of the nation's economic growth and development. This is why each country is placing importance on developing quality human capital (Islam et al., 2016; Pachauri \& Yadav, 2014). According to Azman et al. (2016), knowledge and skills embodied in an individual is human capital that can be created, developed, and managed. This is valuable at many levels of a society. The Human Capital Theory by Becker in 1975 suggests that governments will be able to gain economic success by investing in the education of their citizens. However, Malaysia's human capital is not growing as rapidly compared to other developing countries (Azman et al., 2016). Therefore, it is the nation's mission to further develop its human capital through education.

The Malaysian government is keen on human capital development as it will benefit not only economic growth but also the intellectual capacity of the nation to be at par with other developing nations. Due to that, soft skills are incorporated into the higher education syllabus. This is also due to the fact the employers do not find any limitations with the academic aspects of graduates but only with their soft skills (Selamat et al., 2013). When the government invests in the education of its citizens, it would reap economic benefit in the future. A way for citizens to generate economic benefit is by being employed after obtaining said education. In order to secure employment, soft skills are an added advantage for the university graduates.

This means that the education system of a country needs to be reinforced and critically developed as institutions of learning as they play a very major role in developing human capitals. Institutions of learning should be competent enough to provide quality teaching and learning to their students so that they would be well developed in order to give back to the country as workforce. Universities are institutional hubs where development of human capital takes place through education (Tang, 2019). Universities are vital mechanisms for economic growth and development, and thus they need the support of the government in order to fully develop their potentials. The success of human capital development greatly depends on the quality of the universities, thus emphasis is placed on how to get the best out of higher education. This is why Malaysia has acknowledged the role of universities in generating human capital for the country's development (Azman et al., 2016). Therefore, emphasis needs to be placed on university graduates to develop soft skills in order for the government to fulfill the Human Capital Theory.

\section{The Role of the Government through the Ministry of Higher Education}

The government has restructured the higher education system in order for it to fulfil Vision 2020. Higher education institutions (HEIs) are developed to achieve excellence in the global education market. The history of higher education in Malaysia has undergone four phases: (a) Education for elites, (b) Education for affirmative action, (c) Education as and for business, and (d) Education for global competition (Grapragasem et al., 2014). These phases are all geared towards human capital development.

It is indeed the government's aspiration to develop the country's higher education to be of higher rank and to compete in the global economy. To achieve it, there are five aspirations that the higher education system is based on: 1) Access: to improve enrolment rates in tertiary and higher education especially regards to Technical and Vocational Education and Training (TVET); 2) Quality: to increase employability rate to above $80 \%$ by $2025 ; 3$ ) Equity: to allow all Malaysians to have the opportunity at 
an education regardless of their background; 4) Unity: to ensure that enrolments in HEIs are a mixture of Malaysia's various ethnicities; and 5) Efficiency: to secure placement in the top 25 of 50 countries of Universities 21 (U21) with regards to research, enrolment and employability (Zain et al., 2017).

As can be inferred from the above aspiration, the government is trying by all means to develop the higher education system and inclusivity is not limited to only those with academic excellence but also those with skills through TVET.

According to Da Wan et al. (2018), there are 20 public universities, 30 public polytechnics and 80 public community colleges. The private higher education sector is also booming in numbers with 26 private university colleges and over 350 private colleges in Malaysia. Despite all the HEIs in Malaysia, the quality of our education is still being questioned. Our education system does not have a way to assess progression which is why even though the students have passed certain levels, for example, there is no way to find out their level of proficiency.

Other than that, universities tend to lean towards research and publication, which means that their ranking does not necessarily indicate the quality of teaching and learning (Da Wan et al., 2018). Therefore, the main aim of universities might have been lost in translation. The input of resources invested in HEIs has not yielded expected output. Thus far, there are a lot that Malaysia's HEIs can improve on (Da Wan et al., 2018).

As education plays a huge part in incorporating soft skills, therefore research and expert opinions have been included in determining suitable soft skills that should be included in the syllabus (Pachauri \& Yadav, 2014). The Ministry of Higher Education (MOHE) plays a big role in addressing the concerns of soft skills development in universities by launching a few initiatives to ensure that soft skills are incorporated into HEIs. Along with these initiatives is a launch of the soft skills module in 2006.

A framework has also been drawn up by the MOHE (2006), which consists of the following seven skills: 1) Communication Skills in English; 2) Critical Thinking and Problem-Solving Skills; 3) TeamWorking Skills; 4) Lifelong Learning and Information Management Skills; 5) Entrepreneurial Skills; 6) Moral and Professional Ethics; and 7) Leadership Skills.

All of the above-mentioned skills are essential soft skills that should be acquired by university students by the time they graduate. Although the module was launched since 2006, up until 2017, MOHE has found that graduates are still lacking in certain soft skills (Tang, 2019). This shows that even with the module in place by the government, it is the universities' role to generate and instil soft skills among their graduates.

\section{The Role of Universities}

Universities are where students can obtain knowledge and grow a variety of attitudes and characteristics for personal development and association with society. Along with learning hard skills, soft skills are also requirements for students to obtain during their education period (Tang, 2019). However, the responsibility of universities to prepare their students' with appropriate knowledge and skills is clouded with challenges (Fahimirad et al., 2019). In order to fulfil their responsibility, universities have to ensure that their curriculum and co-curriculum are able to incoporate both hard and soft skills required by graduates for sustainable purposes in the labour market. It was also stated by Fahimirad et al. (2019) that jobs are evolving and in 20 years' time current graduates might be hired for jobs which have not existed yet. These future jobs would certainly require ample soft skills that can be applied across multidisciplines.

The worrisome situation of skills disparity between students' acquired skills and actual skills of labour market demands can be due to universities that are not catering well to the issue. Labour market demands are ever growing and universities need to be prepared by revolutionising the education contents. Universities need to ensure that their role as providers of education are substantial and that their graduates would be imparted with relevant skills set ready for labour market demands (Okolie et al., 2019). Therefore, universities need to also prepare their graduates for the workforce by aligning their curriculum to match current and even future labour market demands.

In a study investigating soft skills, Cimatti (2016) reported that the role of universities does not only include academic aspects but also to create citizens that can participate well in society. This is why the development of soft skills is not only important for students' career but also to support their everyday 
life. Thus, universities need to be able to come up with methodologies and techniques to generate soft skills among their students.

Subsequently, Cimatti (2016) also highlights that a lecturer's job is not only to provide knowledge related to examinations but also to help students develop soft skills too. This can be done when lecturers integrate soft skills in their courses. Soft skills can be embedded in certain courses to develop disciplinerelated skills or through specific activities like projects or case studies. To further support the integration of soft skills, teaching pedagogy should always be updated. Lecturers can include seminars and workshops to give more exposure to their students.

Finally, Cimatti (2016) proposes that universities can collaborate with industries to give students first hand experience of the working world. Visits, internships and joined-programs can open the students' eyes to see the importance of skills in their career and this could indirectly motivate them to constantly develop the necessary skills. This is because soft skills is a lifelong learning process which can be obtained through educational institutions and also through personal experiences by engagement and involvement with the industries.

\section{The Role of Curriculum}

Curriculum encompasses a diverse range that includes process, syllabus, product and practical course. It highlights education as designers set objectives, outcomes and come up with a plan. It helps to implement teaching-learning methods, learning engagement and students' experiences. Curriculum also needs to be continuously assessed in order to know what is valuable. As for higher education, the curriculum is designed with social, economic, physical and cultural environment in mind. It is supposed to identify society and students' needs (Fahimirad et al., 2019). A well-designed curriculum by universities is paramount in achieving not only academic excellence but also the inculcation of skills and competencies. This should be the main goal of policymakers, managers of universities and the lecturers (Okolie et al., 2019). However, effective curriculums are scarce and they are currently designed in a way that do not support the labour market demands as they lack in developing graduates' soft skills.

Many companies have indicated that they find the curriculum of universities are still quite traditional which led to graduates failing at real career situations. Curriculum should be designed to not only develop the students' soft skills but also for them to be effective members of society. Nevertheless, there are some criticisms towards incorporating soft skills in the curriculum. One of it is that soft skills would cause less emphasis to be placed on hard skills causing graduates to lack the knowledge required for their profession. Another criticism is that the soft skills might be restrictive to that particular discipline which then would not support soft skills across multi-disciplines. However, these criticisms could provide the platform for the universities to design a well-balanced curriculum (Fahimirad et al., 2019).

Part of the curriculum to generate soft skills would be an internship stint that undergraduates have to undergo. After going through classroom-based activities for soft skills development, employment-based training is another great platform. Internship periods are suitable for undergraduates to practice their academic skills, hone soft skills and gain real-time experience before entering the real working world (Tang, 2019; Patacsil \& Tablatin, 2017). Universities too can collaborate with companies to enable their students to undergo internship with coaching and mentoring that could further develop soft skills and give them the support they need to transition into the working world (Tang, 2019).

Another curriculum component at universities is the co-curriculum which is a requirement for students to complete their studies. Co-curriculum is essential in generating holistic graduates that are equipped physically, emotionally, spiritually and intellectually (Selamat et al., 2013). According to Selamat et al. (2013), the eight principles of co-curriculum, includes experiential learning, authentic, total learning experience and soft skills. The implementation of co-curriculum is essential in ensuring that students get to experience skills first hand, which can be one of the best way to learn. 


\section{METHODS}

A systematic literature review selects specific articles that can be reviewed and the data collected can be synthesised to answer the research questions (Snyder, 2019). According to Khan et al. (2003), there are five steps to conducting a systemic review. Step 1 is "framing questions for a review" in which the researcher identified the need for a review and came up with four research questions as previously stated in the introduction section. Step 2 is "identifying relevant work". The researcher used online databases such as Scopus and Google Scholar to search for related articles published between years 2015-2020. A combination of terms such as "soft skills", "role of government", "role of universities" and "employers perception" were used to search for the articles. Step 3 is "assessing the quality of studies". In conducting this step, the researcher read the articles thoroughly to ensure they possess the following criteria, i) the study should be centred around the issue of soft skills of students or graduates, ii) the study reports on the views of employers or the government regarding the issue iii) the study reports on universities practices on developing soft skills of the students and iv) priority in selection is given to the study in Malaysian setting. After thorough selection, 16 articles were chosen to extract data in order to answer the research questions. The researcher then tabulated the data from the articles chosen in fulfilling step 4, which is "summarizing the evidence". Lastly, step 5 is "interpreting the findings" and this is further discussed in the following section.

\section{FINDINGS AND DISCUSSION}

This section presents the findings which was discovered by the researcher and the discussion is according to the research questions.

What soft skills do employers value?

Table 1: Soft Skills That Are Valued by Employers

\begin{tabular}{|c|c|c|}
\hline $\begin{array}{c}\text { Article Title } \\
\text { (Authors \& Year) }\end{array}$ & Research Aims & Findings \\
\hline $\begin{array}{l}\text { Graduate } \\
\text { Employability and } \\
\text { Communication } \\
\text { Competence: Are } \\
\text { Undergraduates } \\
\text { Taught Relevant } \\
\text { Skills? } \\
\text { (Clokie \& Fourie, } \\
\text { 2016) }\end{array}$ & $\begin{array}{l}\text { To investigate the } \\
\text { sufficiency of first-year } \\
\text { communication courses in } \\
\text { covering the } \\
\text { communication skills } \\
\text { employers expect } \\
\text { graduates to have. }\end{array}$ & $\begin{array}{l}\text { Communication and employability: } \\
\text { - } \quad \text { oral \& written communication } \\
\text { - } \quad \text { personal attributes of initiative } \\
\text { Interpersonal skills: } \\
\text { - motivation } \\
\text { - listening } \\
\text { teamwork } \\
\text { Business communication skills: } \\
\text { - email writing } \\
\text { - } \text { presentations }\end{array}$ \\
\hline $\begin{array}{l}\text { Soft skills to enhance } \\
\text { graduate } \\
\text { employability: } \\
\text { comparing students } \\
\text { and employers' } \\
\text { perceptions } \\
\text { (Succi \& Canovi, } \\
\text { 2019) }\end{array}$ & $\begin{array}{l}\text { This paper explores } \\
\text { students' as well as } \\
\text { employers' perceptions of } \\
\text { the importance of soft } \\
\text { skills in enhancing } \\
\text { graduate employability. }\end{array}$ & $\begin{array}{l}\text { employers look to hire graduates } \\
\text { with good communication skills, } \\
\text { being committed to work, teamwork } \\
\text { skills and innovative thinking } \\
\text { life balance skills, leadership and } \\
\text { management skills are least } \\
\text { important to employers } \\
\text { employers indicated that students } \\
\text { are not well prepared, they lack of } \\
\text { self-awareness and the ability to }\end{array}$ \\
\hline
\end{tabular}




\begin{tabular}{|c|c|c|}
\hline & & $\begin{array}{l}\text { identify personal strengths and } \\
\text { weaknesses } \\
\text { employers find that universities } \\
\text { offer less exposure to the real world } \\
\text { and this can be overcome by } \\
\text { internships, case studies and } \\
\text { corporate testimonials } \\
\text { employers too find that graduates } \\
\text { have unrealistic expectations } \\
\text { regarding the corporate world and } \\
\text { they lack responsibility in acquiring } \\
\text { and developing soft skills }\end{array}$ \\
\hline $\begin{array}{l}\text { Hard and Soft Skills in } \\
\text { Preparing GIS } \\
\text { Professionals: } \\
\text { Comparing } \\
\text { Perceptions of } \\
\text { Employers and } \\
\text { Educators } \\
\text { (Wikle \& Fagin, 2015) }\end{array}$ & $\begin{array}{l}\text { This article presents } \\
\text { findings from a survey of } \\
\text { GIS employers and } \\
\text { educators concerning the } \\
\text { importance of hard and } \\
\text { soft skills among entry- } \\
\text { level GIS professionals. }\end{array}$ & $\begin{array}{l}\text { Employers value the following soft skills: } \\
\text { - } \quad \text { critical thinking } \\
\text { - } \quad \text { abilitily to work in a team } \\
\text { environment } \\
\text { - } \quad \text { ability to work independently } \\
\text { - } \quad \text { ime management/multitasking } \\
\text { internship experience }\end{array}$ \\
\hline $\begin{array}{l}\text { Employer demands } \\
\text { from } \\
\text { business graduates } \\
\text { (McMurray et al., } \\
\text { 2016) }\end{array}$ & $\begin{array}{l}\text { The purpose of this paper } \\
\text { is to report on research } \\
\text { carried out with employers } \\
\text { to determine demand for } \\
\text { business and management } \\
\text { skills in the Scottish } \\
\text { workforce. }\end{array}$ & 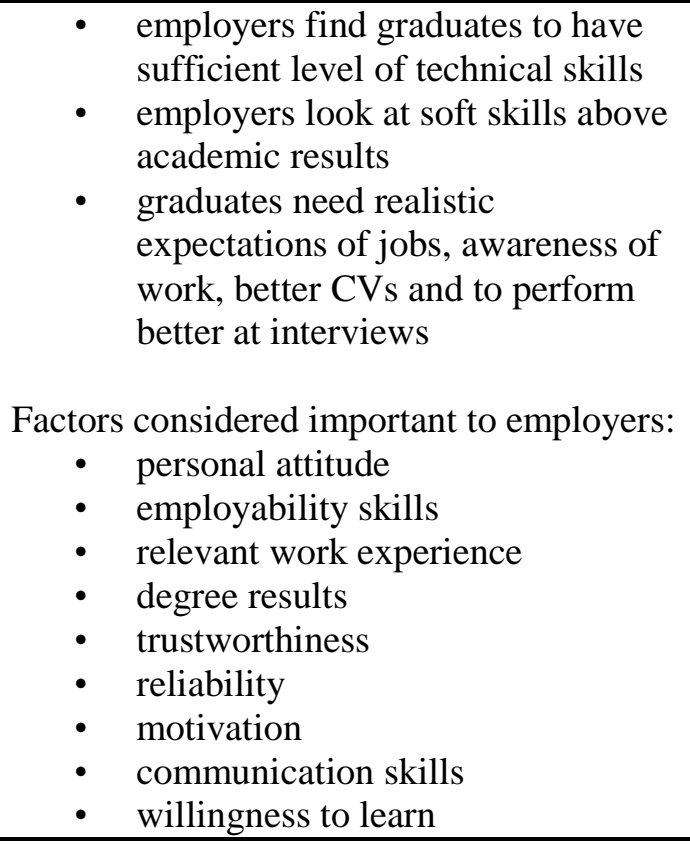 \\
\hline
\end{tabular}

In order to be employed, employers not only look at academic qualifications but also at individuals' soft skill. In a setting where everyone is academically qualified, soft skills can differentiate these graduates and give them positional advantages over their peers (Succi \& Canovi, 2019). Based on the data extracted above, the soft skills that employers value aligns with the soft skills that MOHE is emphasising on via the soft skills module from 2006.

Employers would like to employ graduates who are work-ready. Although experience is to be gained when they start the job, but with adequate soft skills to begin with, it will enable easier employment and faster career progression. One important skill employer's value that is recurring in many research is communication skill. Communication skill includes spoken communication, interpersonal communication and written communication. In fact, from the very moment a graduate applies for a job to during an interview session, a graduate's written and spoken communication is already being assessed (Azmi et al., 2018). According to McMurray et al. (2016), graduates need training in order to perform better at interviews. This shows that many employers are not impressed by the first impression graduates give during interview sessions (Clokie \& Fourie, 2016). Therefore, the ability to communicate 
well is highly valued by employers as it translates into the graduates' ability to carry themselves well. However, despite communication skills being easily integrated and widely taught in universities, it is still a skill that employers find lacking among the graduates.

Employers also look to hire team players. Graduates need to be able to possess teamwork skills and the ability to work in a team. In a research by Hurrell (2016), a manager reported that he would like to see improvement in his employees' soft skills especially team working in particular. Teamwork is a necessity as many individuals in an organisation need to come together and be able to work well with each other.

Employers also value fresh graduates who have prior work experience to a certain extent. This is where internships come in place as it exposes students to the work environment. Having some sort of work experience prepares the graduates for reality and enables them to be aware of what they are lacking and what skills they would need to polish before entering real work situations. Therefore, it is crucial for graduates to have realistic expectation of the work environment (Succi \& Canovi, 2019; McMurray et al., 2016).

Employers' perceptions and opinions concerning graduates' soft skills are crucial as employers are the ones who hire and enable the graduates to secure a job. Hence, the government and universities should pay detailed attention to labour market demands and cater to them. Education needs to always evolve as the labour market is always evolving with time. Education style and system that was effective many years ago is not as useful as current time. It is also in recent years that emphasis has been placed on the development of soft skills which shows the growing importance of it (Succi \& Canovi, 2019).

What soft skills are lacking from university graduates?

Table 2: Soft Skills That Are Lacking from University Graduates

\begin{tabular}{|c|c|c|}
\hline $\begin{array}{c}\text { Article Title } \\
\text { (Author \& Year) }\end{array}$ & Research Aims & Findings \\
\hline $\begin{array}{l}\text { Assessing Students' } \\
\text { Knowledge and Soft } \\
\text { Skills Competency in } \\
\text { the Industrial Training } \\
\text { Programme: The } \\
\text { Employers' } \\
\text { Perspective } \\
\text { (Chiu et al., 2016) }\end{array}$ & $\begin{array}{l}\text { To evaluate the knowledge } \\
\text { and soft skills competency } \\
\text { from the employer's } \\
\text { viewpoints on the } \\
\text { Universiti Utara Malaysia } \\
\text { (UUM) students } \\
\text { participating in the } \\
\text { industrial training } \\
\text { programme. }\end{array}$ & $\begin{array}{ll}\text { - } & \text { students could improve on practical } \\
\text { skills, leadership qualities, and } \\
\text { discipline } \\
\text { students seem to face difficulties in } \\
\text { understanding new environments } \\
\text { students lack the ability to } \\
\text { communicate in English confidently } \\
\text { students need to have good basic } \\
\text { knowledge on some technical aspects } \\
\text { and hands-on skill } \\
\text { students can acquire basic accounting } \\
\text { and financial skills, critical thinking } \\
\text { and organization management skills } \\
\text { students have the discipline-related } \\
\text { knowledge but are not equipped with } \\
\text { more than that }\end{array}$ \\
\hline $\begin{array}{l}\text { Gaps Between } \\
\text { Industry Expectations } \\
\text { and the Abilities of } \\
\text { Graduates } \\
\text { (Radermacher \& } \\
\text { Walia, 2013) }\end{array}$ & $\begin{array}{l}\text { This paper identifies and } \\
\text { classifies knowledge } \\
\text { deficiencies found in } \\
\text { graduating computer } \\
\text { science students for the } \\
\text { purpose of better preparing } \\
\text { students for their future } \\
\text { careers in academia or } \\
\text { industry. }\end{array}$ & $\begin{array}{l}\text { Graduates lack the ability: } \\
\text { - } \quad \text { to communicate with customers } \\
\text { to communicate when they were in } \\
\text { need of assistance or struggling with } \\
\text { - } \text { a problem } \\
\text { - } \text { to listen well } \\
\text { detail in written communication } \\
\text { - of project management skills } \\
\text { - } \\
\text { to work as part of a cross- } \\
\text { disciplinary team }\end{array}$ \\
\hline
\end{tabular}




\begin{tabular}{|c|c|c|}
\hline & & $\begin{array}{l}\text { - } \text { to generate alternate solutions to } \\
\text { problems } \\
\text { that can make them good candidates } \\
\text { for group leader roles }\end{array}$ \\
\hline $\begin{array}{l}\text { Gauging Industry's } \\
\text { Perspectives on Soft } \\
\text { Skills of Graduate } \\
\text { Architects: } \\
\text { Importance vs } \\
\text { Satisfaction } \\
\text { (Salleh et al., 2015) }\end{array}$ & $\begin{array}{l}\text { This paper aims to gauge } \\
\text { the industry's views and } \\
\text { satisfaction of graduate } \\
\text { architects upon entering } \\
\text { their employment. }\end{array}$ & $\begin{array}{l}\text { Employers found the graduates were lacking } \\
\text { in: } \\
\text { - English languages abilities } \\
\text { - written presentation } \\
\text { - } \text { oritten communication } \\
\text { - negotiation skills } \\
\text { - } \text { analytical \& critical thinking }\end{array}$ \\
\hline $\begin{array}{l}\text { Mixed Signals: Do } \\
\text { College Graduates } \\
\text { Have the Soft Skills } \\
\text { That Employers } \\
\text { Want? } \\
\text { (Stewart et al., 2016) }\end{array}$ & $\begin{array}{l}\text { This paper explores the } \\
\text { soft skills considered most } \\
\text { valuable in today's job } \\
\text { market, as well as the level } \\
\text { of preparedness in recent } \\
\text { college graduates, from } \\
\text { the perspective of both } \\
\text { employer and college } \\
\text { student. }\end{array}$ & $\begin{array}{l}\text { the soft skills in which college } \\
\text { graduates feel competent are the } \\
\text { same that employers feel the } \\
\text { graduates fall short of possessing } \\
\text { the soft skills graduates need to } \\
\text { improve on are problem-solving, } \\
\text { written and verbal communication } \\
\text { and teamwork } \\
\text { students too seem to be over self- } \\
\text { confident which can lead to self- } \\
\text { centredness that leads to problems } \\
\text { in relationships and careers }\end{array}$ \\
\hline
\end{tabular}

Based on the findings, the soft skills that graduates are lacking in are the soft skills valued by employers. Not only that, graduates are not well aware of their own shortcomings. They find themselves competent in soft skills much to employers' disagreement (Stewart et al., 2016). This is a deterrent in the development of soft skills among graduates as there is no system to assess their level of soft skills, and thus they do not know their own strengths and weaknesses for employement purposes.

Critical thinking and problem solving are skills that go together and are lacking among graduates. According to a survey by Desai et al. (2016), employers reported that critical thinking would only become more important with labour market demands. In fact, the study further reports that employers are more interested in hiring graduates with good critical thinking and problem solving skills. Here the importance of it is indisputable yet it is prevalently lacking among university graduates.

According to the research by Chiu et al. (2016), employers recommended students to acquire basic accounting and financial skills, skills that seem to be discipline related. Acquiring these additional skills can give graduates a little extra advantage as they have something more to bring to the table. Also, basic accounting and financial skills can be considered as transferable skills. Transferable skills can be used inter-discipline and they are basically useful at any point of an individual's career. It is also in line with Radermacher and Walia's (2013) research that graduates lack the ability to work as part of a crossdisciplinary team. Therefore, having transferable skills, which can also be perceived in the form of soft skills, give graduates the flexibility to adapt in many different situations.

Malaysian graduates are always reported to be lacking in English proficiency (Chiu et al. 2016; Salleh et al. 2015). English fluency and the ability to communicate in English confidently are skills highly valued by employers yet is still lacking among graduates (Azmi et al., 2018). Despite it being an important skill, students do not make efforts to acquire it well. This supports the fact that graduates are not aware of their own shortcomings, thus there is the mismatch between graduates' perceptions and employers' expectations (Zainuddin et al., 2019; Amiruddin et al., 2016). 


\section{How can the university address the lack of soft skills among graduates?}

Table 3: Ways Universities Can Address the Lack of Soft Skills

\begin{tabular}{|c|c|c|}
\hline $\begin{array}{c}\text { Article Title } \\
\text { (Author \& Year) }\end{array}$ & Research Aims & Findings \\
\hline $\begin{array}{l}\text { Definition, } \\
\text { Development, } \\
\text { Assessment of Soft } \\
\text { Skills and their Role } \\
\text { for the Quality of } \\
\text { Organizations and } \\
\text { Enterprises } \\
\text { (Cimatti, 2016) }\end{array}$ & $\begin{array}{l}\text { To provide a complete } \\
\text { view on soft skills and on } \\
\text { their importance in order } \\
\text { to achieve quality in any } \\
\text { job and more widely in an } \\
\text { individual's life, starting } \\
\text { from soft skills' definition, } \\
\text { learning and assessment. }\end{array}$ & 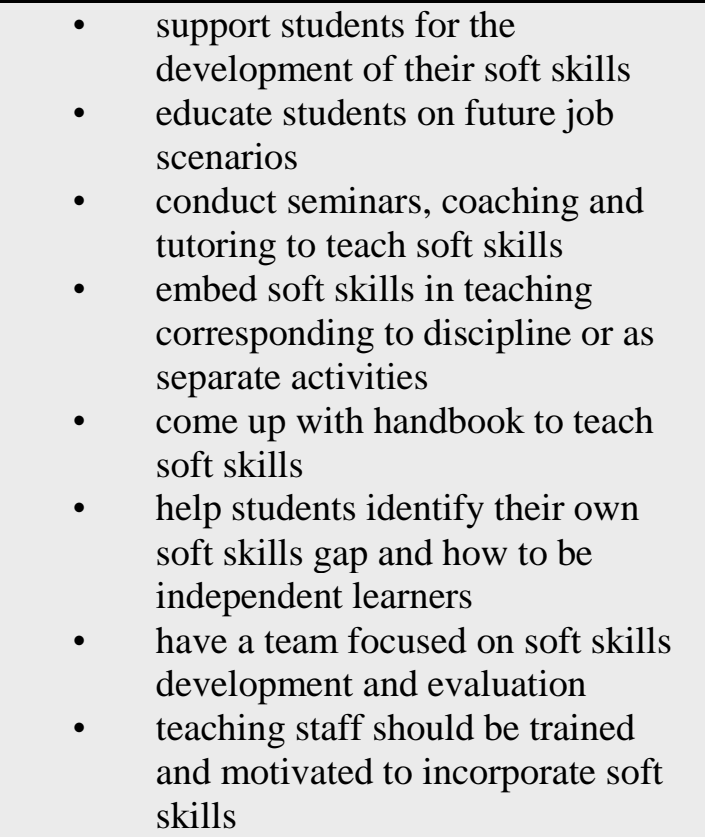 \\
\hline $\begin{array}{l}\text { Public University } \\
\text { Educators' } \\
\text { Understanding and } \\
\text { Conception of Soft } \\
\text { Skills for Educators } \\
\text { (Md-Ali et al., 2016) }\end{array}$ & $\begin{array}{l}\text { The purpose of this paper } \\
\text { is to provide a glimpse } \\
\text { into three educators' } \\
\text { perceptions and } \\
\text { conceptions of soft skills. }\end{array}$ & 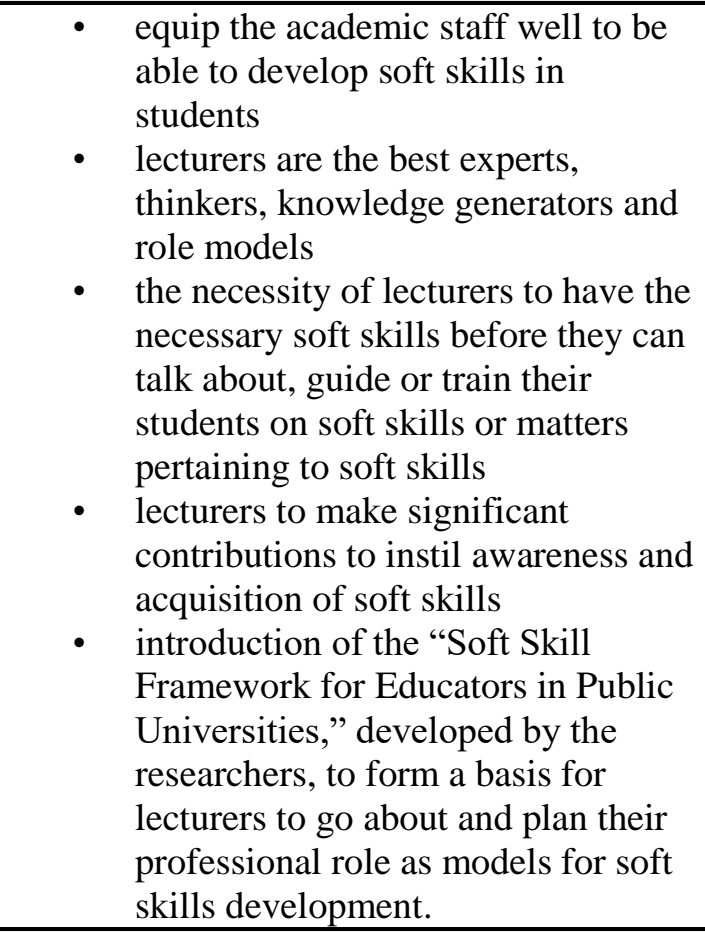 \\
\hline $\begin{array}{l}\text { Web-Based Language } \\
\text { Learning for } \\
\text { Enhancing Students' } \\
\text { Soft Skills in Mount } \\
\text { Kenya University } \\
\text { (Ongonda \& Muindi, } \\
\text { 2019) }\end{array}$ & $\begin{array}{l}\text { This study aims to } \\
\text { demonstrate that the } \\
\text { combination of Task- } \\
\text { Based Language Teaching } \\
\text { (TBLT) and web-based } \\
\text { language learning } \\
\text { enhances student's ability } \\
\text { to acquire soft skills that }\end{array}$ & $\begin{array}{l}\text { the use of technology can develop } \\
\text { soft skills in ESL learners by } \\
\text { implementing task-based } \\
\text { assignments } \\
\text { CALL is beneficial for their overall } \\
\text { soft skills acquisition } \\
\text { Speaking Skills: }\end{array}$ \\
\hline
\end{tabular}




\begin{tabular}{|c|c|c|}
\hline & $\begin{array}{l}\text { are paramount in their real } \\
\text { life. }\end{array}$ & 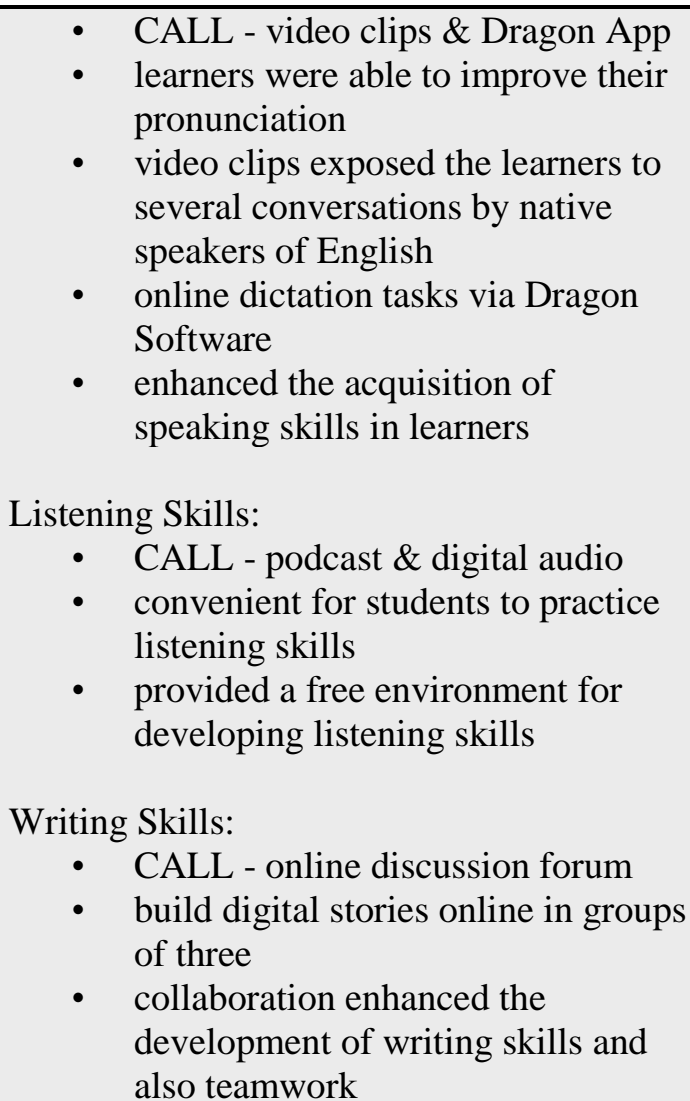 \\
\hline $\begin{array}{l}\text { Exploration of } \\
\text { Internship Experience } \\
\text { and Satisfaction } \\
\text { Leading to Better } \\
\text { Career Prospects } \\
\text { among Business } \\
\text { Students in UAE } \\
\text { (Jawabri, 2017) }\end{array}$ & $\begin{array}{l}\text { To explore the role of } \\
\text { internship experience and } \\
\text { satisfaction resulting in } \\
\text { better career prospects } \\
\text { among the students } \\
\text { studying business in UAE. }\end{array}$ & $\begin{array}{l}\text { - } \text { inculcation of new skills indeed had } \\
\text { a strong association with the } \\
\text { internship experience, with learning } \\
\text { of new skills } \\
\text { universities enabled students to } \\
\text { actively engage in the internship } \\
\text { programmes. } \\
\text { - students were provided with } \\
\text { sufficient supervision } \\
\text { - students were also found to be } \\
\text { equipped with necessary soft skills } \\
\text { students felt more prepared to enter } \\
\text { the working world, } \\
\text { internship opportunities impact the } \\
\text { development of soft skills of the } \\
\text { student }\end{array}$ \\
\hline
\end{tabular}

Universities are where students acquire hard skills and along with it soft skills. Education needs to evolve from teaching students to being economically productive to emphasising on their holistic development (Cimatti, 2016). The mindset that students have is very much academic-based and examoriented. Many graduates thik that with good results, they will be able to secure a good job. However, employers are looking for individuals with good soft skills. This is where universities play a huge role in developing soft skills among their students while they were studying at the university.

Embedding soft skills into courses is one the best way to ensure students' development. This means that universities would need to prepare their academic staff to be able to integrate soft skills in their courses. Cimmati (2016) proposes universities to have dedicated teams towards development of soft skills that can also train the academic staff. The plan is not to undermine lecturers but as according to Md-Ali et al. (2016), lecturers themselves need to have the necessary soft skills first before being able to talk, guide and train students on soft skills development. Lecturers are knowledge generators and role models 
to students, so effective incorporation of soft skills is seen necessary. It will also be helpful if handbooks or frameworks can be developed to guide lecturers on how to go about developing soft skills among their students.

The advancement of technology is very useful in education. It can also be used to develop soft skills as Ongonda and Muindi (2019) used task-tased and web-based language learning to enable students to acquire soft skills via technology. The management of universities can support pedagogical aspects of their lecturers by providing appropriate materials for the ease of technological implementation in developing soft skills. This is also in line with Malaysia's education system which inculcates $21 \mathrm{st}$ century teaching and learning.

Nonetheless, the best way for students to develop soft skills would be by hands-on learning experiences. Internships enable students to be equipped with soft skills and enable them to be better prepared to enter the job market (Jawabri, 2017). This can be made possible when universities make internship stints as part of a curriculum. However, universities need to strictly oversee the internship program in order to ensure that students reap the best benefits of it and they are not being exploited as free labours.

Universities play a huge role in providing the platform and engaging students with soft skills. It also has the responsibility to deliver what graduates expect out of their education at a university, which is to gain discipline-based knowledge and to be employed after graduation.

How can the government address the lack of soft skills among graduates?

Table 4: Ways the Government can Address the Lack of Soft Skills

\begin{tabular}{|c|c|c|}
\hline $\begin{array}{c}\text { Article Title } \\
\text { (Author \& Year) }\end{array}$ & Research Aims & Findings \\
\hline $\begin{array}{l}\text { Soft skills at the } \\
\text { Malaysian institutes } \\
\text { of higher learning } \\
\text { (Shakir, 2009) }\end{array}$ & $\begin{array}{l}\text { This article discusses } \\
\text { human capital } \\
\text { development through soft } \\
\text { skills elements. }\end{array}$ & 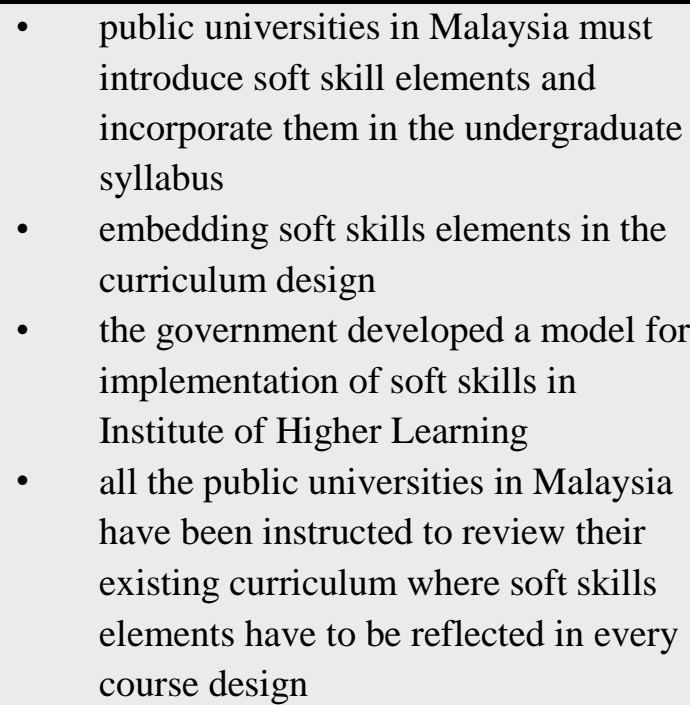 \\
\hline $\begin{array}{l}\text { Education in Malaysia } \\
\text { Towards a Developed } \\
\text { Nation } \\
\text { (Da Wan et al., 2018) }\end{array}$ & $\begin{array}{l}\text { To provide a critical } \\
\text { assessment of the state of } \\
\text { education in Malaysia. }\end{array}$ & $\begin{array}{l}\text { - emphasis on the third strategic thrust in } \\
\text { 11MP } \\
\text { give equal emphasis to TVET as the } \\
\text { equivalent to academic pathway } \\
\text { - increase efficiency and effectiveness of } \\
\text { TVET } \\
\text { - streamline programmes to meet the needs } \\
\text { of industry } \\
\text { - MOOC \& flexible learning better access } \\
\text { to technology and connectivity } \\
\text { - autonomy for Higher Education } \\
\text { Institutions }\end{array}$ \\
\hline
\end{tabular}




\begin{tabular}{|c|c|c|}
\hline & & $\begin{array}{l}\text { - empower STEM that would lead to the } \\
\text { idea of a scientific and technological } \\
\text { civilisation } \\
\text { - Higher Education Student Loan Fund } \\
\text { (PTPTN) has been a major supporting tool } \\
\text { to increase access and enhance equity in } \\
\text { higher education }\end{array}$ \\
\hline $\begin{array}{l}\text { Employability for } \\
\text { music graduates: } \\
\text { Malaysian educational } \\
\text { reform and the focus } \\
\text { on generic skills } \\
\text { (Ghazali \& Bennett, } \\
\text { 2017) }\end{array}$ & $\begin{array}{l}\text { This article presents an } \\
\text { overview of the whole-of- } \\
\text { education trends in } \\
\text { Malaysia }\end{array}$ & $\begin{array}{l}\text { - introduction of Malaysian Education } \\
\text { Blueprint to cater to the diverse } 21 \text { st- } \\
\text { century labor market and concerns about } \\
\text { employability among Malaysian youth } \\
\text { - the MOE should review the school } \\
\text { curriculum } \\
\text { - exam oriented setting deters the } \\
\text { development of soft skills } \\
\text { - focus on higher education graduate } \\
\text { employability and the development of } \\
\text { transferable skills } \\
\text { - the National Graduate Employability } \\
\text { Blueprint to focus on what is required for } \\
\text { graduates to secure and sustain } \\
\text { employment } \\
\text { - government should implement new ideas } \\
\text { and measures in tertiary education in } \\
\text { ensuring a more prepared and holistic } \\
\text { graduate with better chances of } \\
\text { employability }\end{array}$ \\
\hline $\begin{array}{l}\text { Graduate work- } \\
\text { readiness in the Asia- } \\
\text { Pacific region: } \\
\text { Perspectives from } \\
\text { stakeholders and the } \\
\text { role of HRM } \\
\text { (Verma et al., 2018) }\end{array}$ & $\begin{array}{l}\text { This paper proposes a } \\
\text { stakeholder-oriented HRM } \\
\text { model involving HR } \\
\text { professionals from three } \\
\text { main stakeholders; } \\
\text { government, industry and } \\
\text { educational institutes, in } \\
\text { an 'inside-out' strategy to } \\
\text { address the identified } \\
\text { graduate work-readiness } \\
\text { challenges. }\end{array}$ & $\begin{array}{l}\text { - government funding and support to boost } \\
\text { research and development by universities } \\
\text { with the intention of exploring new ideas } \\
\text { - creating feedback loops between } \\
\text { stakeholders on industry trends and } \\
\text { graduate skills requirements } \\
\text { - help educators to develop evidence-based } \\
\text { graduate programs } \\
\text { - providing scholarships for doctorate } \\
\text { programs in industry } \\
\text { - involving student unions } \\
\text { - establish a labour market intermediary } \\
\text { network with the intention of } \\
\text { strengthening links between the supply } \\
\text { and demand sides of the labour market } \\
\text { - develop sector skills councils } \\
\text { - HRM professionals from government may } \\
\text { be involved with their counterparts in } \\
\text { industry and educational institutions, to } \\
\text { formulate and improve policies, } \\
\text { streamline quality assurance practices, and } \\
\text { prepare reports on the work-readiness } \\
\text { challenges in specific industry and } \\
\text { education sectors } \\
\text { - extending HRM professionals' roles with } \\
\text { regard to their relationships with }\end{array}$ \\
\hline
\end{tabular}




\begin{tabular}{|l|l|}
\hline & $\begin{array}{l}\text { governments, industry and educational } \\
\text { institutions } \\
\text { involving industry more in curriculum } \\
\text { development and emphasising demand-led } \\
\text { approaches in industry to recruit from } \\
\text { priority client groups } \\
\text { emphasised the need for policies to } \\
\text { provide grants and special incentives for } \\
\text { organisations that have effective } \\
\text { collaboration with universities }\end{array}$ \\
\hline
\end{tabular}

The government through MOE is aware that education is about developing holistic individuals who are competent, skilled and efficient for the labour force. However, there is a striking contrast between the government's aspirations and the current outcome of graduates. It is also a challenge to address it and the government is trying its best by introducing many initiatives. The introduction of Malaysia Education Blueprint 2013 - 2025, Malaysia Education Blueprint (Higher Education) 2015 - 2025 and National Higher Education Strategic Plan 2007 - 2020 are all geared towards developing human capital through education (Da Wan et al., 2018).

The government is constantly coming up with initiatives which can assist the soft skills development of its human capital. According to Shakir (2009), MOHE has made it mandatory to incorporate soft skills elements in HEIs curriculum. This is seen by the development of the soft skills module in 2006. It is also important for the government to support universities. This can be done by funding research and development to figure out labour market demands. It can also be useful to establish a labour market intermediary network to link the supply (universities) and demand (employers) of the labour market (Verma et al., 2018). Once labour market demands are established, the data can be put to use by the government in generating policies to develop soft skills among university graduates.

Malaysia's graduates' unemployment rate is at 3.3\% as of October 2019 (Lim, 2019). Fortunately the percentages have dropped from $3.9 \%$ in 2018 but it is still quite a huge population. With the development of soft skills among graduates, it is also crucial for employment opportunities to rise to accommodate the increasing rates of qualified workers. Here the government plays a huge role in generating job opportunities. The Malaysian government has launched an initiative called Malaysia@Kerja to generate 350,000 job opportunities in the next five years (Husain, 2019). This initiative does not only open job vacancies but also enable those unemployed to gain skills and competencies to survive in the labour market.

\section{CONCLUSION}

Through this research, it has been found that graduates lack soft skills that employers value and look for. Graduates are not aware of this situation which contributes to the slow development of soft skills among university graduates. To solve this ongoing issue, both the university and the government are making efforts to develop holistic graduates ready for the labour market. This collaborative efforts are necessary for the development of steady economic progression in our country. More importantly, the development of soft skills in university graduates can create holistic individuals for the betterment of the nation. This study implicates the necessity for all higher institutions to review their initiatives in developing soft skills and create mechanisms to assess this development among their graduates. 


\section{REFERENCES}

Amiruddin, M. H., Ngadiman, N., Abdul Kadir, R., \& Saidy, S. (2016). Review of soft skills of tvet trainees from the malaysian advanced technology training center (ADTEC). Journal of Technical Education and Training, 8(1), 14-24.

Azman, N., Sirat, M., \& Pang, V. (2016). Managing and mobilising talent in Malaysia: issues, challenges and policy implications for Malaysian universities. Journal of Higher Education Policy and Management, 38(3), 316-332.

Azmi, I. A. G., Hashim, R. C., \& Yusoff, Y. M. (2018). The employability skills of Malaysian university students. International Journal of Modern Trends in Social Sciences, 1(3), 1-14.

Chiu, K. K., Mahat, N. I., Rashid, B., Razak, N. A., \& Omar, H. (2016). Assessing Students' Knowledge and Soft Skills Competency in the Industrial Training Programme: The Employers' Perspective. Rev. Eur. Stud., $8,123$.

Cimatti, B. (2016). Definition, development, assessment of soft skills and their role for the quality of organizations and enterprises. International Journal for quality research, 10(1).

Clokie, T. L., \& Fourie, E. (2016). Graduate employability and communication competence: Are undergraduates taught relevant skills?. Business and Professional Communication Quarterly, 79(4), 442-463.

Da Wan, C., Sirat, M., \& Razak, D. A. (2018). Education in Malaysia Towards a Developed Nation.

Desai, M. S., Berger, B. D., \& Higgs, R. (2016). Critical thinking skills for business school graduates as demanded by employers: a strategic perspective and recommendations. Academy of Educational Leadership Journal, 20(1), 10-31.

Fahimirad, M., Nair, P. K., Kotamjani, S. S., Mahdinezhad, M., \& Feng, J. B. (2019). Integration and Development of Employability Skills into Malaysian Higher Education Context: Review of the Literature. International Journal of Higher Education, 8(6).

Ghazali, G., \& Bennett, D. (2017). Employability for music graduates: Malaysian educational reform and the focus on generic skills. International Journal of Music Education, 35(4), 588-600.

Grapragasem, S., Krishnan, A., \& Mansor, A. N. (2014). Current Trends in Malaysian Higher Education and the Effect on Education Policy and Practice: An Overview. International Journal of Higher Education, 3(1), 85-93.

Gruzdev, M. V., Kuznetsova, I. V., Tarkhanova, I. Y., \& Kazakova, E. I. (2018). University Graduates' Soft Skills: The Employers' Opinion. European Journal of Contemporary Education, 7(4), 690-698.

Hurrell, S. A. (2016). Rethinking the soft skills deficit blame game: Employers, skills withdrawal and the reporting of soft skills gaps. Human Relations, 69(3), 605-628.

Husain, N. H. (2019, October 11). Inisiatif Malaysia@Kerja wujud 350,000 peluang pekerjaan. Retrieved from https://www.sinarharian.com.my/article/51606/KHAS/Belanjawan-2020/Inisiatif-Malaysia@ Kerjawujud-350000-peluang-pekerjaan

Islam, R., Ghani, A. B. A., Kusuma, B., \& Theseira, B. B. (2016). Education and human capital effect on Malaysian economic growth. International Journal of Economics and Financial Issues, 6(4), 1722-1728.

Jawabri, A. (2017). Exploration of Internship Experience and Satisfaction Leading to Better Career Prospects among Business Students in UAE. American Journal of Educational Research, 5(10), 1065-1079.

Khan, K. S., Kunz, R., Kleijnen, J., \& Antes, G. (2003). Five steps to conducting a systematic review. Journal of the royal society of medicine, 96(3), 118-121.

Lim, J. (2019, October 11). Malaysia 2020 unemployment rate seen at 3.3\%. Retrieved from https://www.theedgemarkets.com/article/malaysia-2020-unemployment-rate-seen-33

Malaysia, K. P. T. (2006). Modul pembangunan kemahiran insaniah (soft skills) untuk institusi pengajian tinggi Malaysia. Serdang: Universiti Putra Malaysia, 1-52.

McMurray, S., Dutton, M., McQuaid, R., \& Richard, A. (2016). Employer demands from business graduates. Education+ Training.

Md-Ali, R., Shaffie, F., \& Yusof, F. M. (2016). Public university educators' understanding and conception of soft skills for educators. International Review of Management and Marketing, 6(7S), 181-186.

Okolie, U. C., Nwosu, H. E., \& Mlanga, S. (2019). Graduate employability: How the higher education institutions can meet the demand of the labour market. Higher Education, Skills and Work-Based Learning. Epub ahead of print, 26.

Ongonda, A., \& Muindi, M. N. (2019). Web-Based Language Learning for Enhancing Students' Soft Skills in Mount Kenya University. JOURNAL OF ADVANCES IN LINGUISTICS, 10, 1555-1563.

Orji, N. S. (2013). Assessment of employability skills development opportunities for senior secondary school chemistry students. Journal of Educational Research and Reviews, 1(2), 16-26.

Pachauri, D., \& Yadav, A. (2014). Importance of soft skills in teacher education programme. International Journal of Educational Research and Technology, 5(1), 22-25. 
Patacsil, F. F., \& Tablatin, C. L. S. (2017). Exploring the importance of soft and hard skills as perceived by IT internship students and industry: A gap analysis. Journal of Technology and Science Education, 7(3), 347-368.

Radermacher, A., \& Walia, G. (2013, March). Gaps between industry expectations and the abilities of graduates. In Proceeding of the 44th ACM technical symposium on Computer science education (pp. 525-530).

Salleh, R., Yusoff, M. A. M., Harun, H., \& Memon, M. A. (2015). Gauging Industry's Perspectives on Soft Skills of Graduate Architects: Importance vs Satisfaction. Global Business \& Management Research, 7(2).

Selamat, J. H., Ismail, K. H., Ahmad, A., Hussin, M. H., \& Seliman, S. (2013). Framework of soft skills infusion based on learning contract concept in Malaysia higher education. Asian Social Science, 9(7), 22.

Shakir, R. (2009). Soft skills at the Malaysian institutes of higher learning. Asia Pacific Education Review, 10(3), 309-315.

Snyder, H. (2019). Literature review as a research methodology: An overview and guidelines. Journal of Business Research, 104, 333-339.

Stewart, C., Wall, A., \& Marciniec, S. (2016, July). Mixed signals: Do college graduates have the soft skills that employers want?. In Competition Forum (Vol. 14, No. 2, p. 276). American Society for Competitiveness.

Succi, C., \& Canovi, M. (2019). Soft skills to enhance graduate employability: comparing students and employers' perceptions. Studies in Higher Education, 1-14.

Tang, K. N. (2019). Beyond Employability: Embedding Soft Skills in Higher Education. Turkish Online Journal of Educational Technology-TOJET, 18(2), 1-9.

Tsaoussi, A. I. (2020). Using soft skills courses to inspire law teachers: a new methodology for a more humanistic legal education. The Law Teacher, 54(1), 1-30.

Verma, P., Nankervis, A., Priyono, S., Moh'd Saleh, N., Connell, J., \& Burgess, J. (2018). Graduate workreadiness challenges in the Asia-Pacific region and the role of HRM. Equality, Diversity and Inclusion: An International Journal.

Wikle, T. A., \& Fagin, T. D. (2015). Hard and soft skills in preparing GIS professionals: Comparing perceptions of employers and educators. Transactions in GIS, 19(5), 641-652.

Zain, N. M., Aspah, V., Abdullah, N., \& Ebrahimi, M. (2017). Challenges and evolution of higher education in Malaysia. UMRAN-International Journal of Islamic and Civilizational Studies, 4(1-1).

Zainuddin, S. Z. B., Pillai, S., Dumanig, F. P., \& Phillip, A. (2019). English language and graduate employability. Education+ Training. 